\title{
Small Hands, Nasty Women, and Bad Hombres: Hegemonic Masculinity and Humor in the 2016 Presidential Election
}

Socius: Sociological Research for a Dynamic World Volume X: I-16

(C) The Author(s) 2017 Reprints and permissions: sagepub.com/journalsPermissions.nav DOI: 10.1 I77/2378023। I7749380 srd.sagepub.com

(S)AGE

\section{Michelle Smirnova'}

\begin{abstract}
Given that the president is thought to be the national representative, presidential campaigns often reflect the efforts to define a national identity and collective values. Political humor provides a unique lens through which to explore how identity figures into national politics given that the critique of an intended target is often made through popular cultural scripts that often inadvertently reify the very power structures they seek to subvert. In conducting an analysis of 240 tweets, memes, and political cartoons from the 2016 U.S. presidential election targeting the two frontrunners, Hillary Clinton and Donald Trump, we see how popular political humor often reaffirmed heteronormative assumptions of gender, sexuality, and race and equated scripts of hegemonic masculinity with presidential ability. In doing so, these discourses reified a patriarchal power structure.
\end{abstract}

\section{Keywords}

gender, hegemonic masculinity, memes, humor, politics

\section{Introduction}

On November 8, 2016, Republican candidate Donald Trump was elected president of the United States over Democratic candidate Hillary Clinton. Gender was a particularly salient feature of the 2016 U.S. presidential election because Clinton was the first woman to be a major party presidential nominee; however, gender has always been a central feature of presidential elections (Katz 2016) and of nationalism in general (Collins 1998; Connell 1995; Nagel 1998). Campaigns for the presidency reflect the struggle to define national identity, particularly in regard to its racial, gender, sexual, class, and religious contours (Collins 2006; Katz 2016). As the national representative, the president of the United States is thought to embody the national identity and its collective values and given that the nation-state is coded masculine, (he) personifies "not only 'America,' but American manhood" (Katz 2016:4). Therefore, it is no wonder that Donald Trump, along with almost every U.S. president before him, stands at the intersection of the many culturally celebrated (and privileged) versions of masculinity as a tall, white, heterosexual, wealthy, cisgender man.

The politics of masculinity in the 2016 presidential election reveals as much about the matrimony between hegemonic masculinity and state power as it does the mechanisms by which patriarchal power subjugates or excludes women, the LGTBQ community, people of color, and other marginalized populations. Hegemonic masculinity is directly linked to patriarchy in that it exists as the form of masculinity that is "culturally exalted" in a particular historical and geographical context (Connell 1995:77) but also in that it reflects dominance over women and subjugated masculinities. It takes the form of patterned practices and ideologies that justify and legitimate "a hierarchical relationship between men and women and among men" within an institutionalized patriarchy (Connell and Messerschmidt 2005:832).

Hegemonic masculinity requires support not only from those at the top but also "less powerful men's (and many women's) consent and complicity with the institutions, social practices, and symbols that ensure some men's privileges" if it is to succeed as a strategy of domination (Messner 2007:465). In doing so, it reflects both cultural hegemony in which people willfully participate in their own subjugation and oppression

'University of Missouri, Kansas City, MO, USA

\section{Corresponding Author:}

Michelle Smirnova, University of Missouri, Kansas City, 5100 Rockhill Road, Kansas City, MO 64III, USA.

Email: smirnovam@umkc.edu 
(Gramsci, Hoare, and Nowell-Smith 1971) as well as the "matrix of domination" (Collins 1990) that defines, constructs, and entraps individuals in multiple intersecting structures of oppression. This is why it can be so difficult to dismantle or subvert: Actions taken to challenge a contender's legitimacy may (unintentionally) use and thereby strengthen the very structures it seeks to subvert. For example, transgender individuals who challenge the assumed alignment of their assigned sex and experienced gender identity still often strive "to 'pass' as a 'normal' gendered person, a goal that is necessary for solving problems of daily life but is not one that disrupts the gendered social order" (Lorber 2005:26). Building on this argument, I consider how online humor aimed to critique Clinton and Trump as presidential candidates often reaffirms heteronormative assumptions of gender, sexuality, and race and equates scripts of hegemonic masculinity with presidential ability. In conducting an analysis of 240 tweets, memes, and political cartoons, I demonstrate how this set of discourses ultimately reifies a patriarchal power structure that privileges a cisgender, heterosexual, white, wealthy, man who is constructed as hegemonically masculine.

Although it often deals with serious topics such as politics or violence, humor is often not treated seriously given that it is just a joke. Such dismissal or oversight may in fact empower those voices that otherwise go unheard. In Domination and the Arts of Resistance, Scott (1990) draws attention to acts that are not traditionally recognized as rebellion or dissent (e.g., feet dragging, working slower, community events, music) to demonstrate how actions not recognized as political manage to chip away at such institutions through prolonged, unrecognized, subversive tactics. By exposing the inconsistencies between ideology and practice, political humor is one such tactic that has the ability to puncture a national ideology in powerful ways (Smirnova 2014).

However, humor can also reproduce cultural hegemony precisely by winning people's consent through laughter. As Billig (2005) argues, some humor strengthens the political structures it allegedly targets by failing to engage in serious criticism; instead, the humor acts as a "safety valve" to reduce discomfort but does not take on the difficult, laborious action to dismantle the structures that produce the underlying injustice. For example, Bridges's (2010) study of "Walk a Mile in Her Shoes" marches, where men walk a mile in high heels, highlights how men often restabilize "relations of gender and sexual inequality" in their participation in this event by "unintentionally reinforce[ing] the taken-forgranted view that femininity and masculinity and homosexuality and heterosexuality are completely different and opposed" (Bridges 2010:19, 21-22). As many laugh at the "joke" nature of the march, they often reaffirm the very inequalities they allegedly seek to address. Humor thus reveals the challenges implicit in dismantling hegemonic masculinity and the patriarchy that empowers it (Connell 1995; Johnson 2005).
Humor makes explicit the implicit contradictions inherent in politics and society more broadly. As such, this paper uses online humor as data to explore how political humor targeting the two frontrunners of the 2016 U.S. presidential election, Hillary Clinton and Donald Trump, reflects both the articulations of oppositional resistance as well as the reification of patriarchal power structures through the invocation of hegemonic masculinity scripts. Using content analysis paired with a critical discourse analysis, I demonstrate how the race to rule and represent the United States as president involved the discursive construction of hegemonic masculinity as synonymous with presidential fitness and in turn constructs women and nonwhite and nonheterosexual men as unfit.

\section{Background}

\section{Masculinities, the Body, Domination}

While masculinities are plural, contradictory, and constantly evolving, hegemonic masculinity is "the configuration of gender practices ... which guarantees (or is taken to guarantee) the dominant position of men and the subordination of women" (Connell 1995:77). Patriarchy is maintained through definitions of masculinity that designate men as superior to women and subordinate others (nonwhite or nonheterosexual men) through a combination of positivist (what men are), normative (what they ought to be), essentialist (core features of masculinity), and semiotic (masculinity as not femininity) qualities (Connell 1995).

Hegemonic masculinity can be understood as the expression and articulation of gender that arose in the context of modern capitalism. This ideology both supports and derives privilege from patriarchy, the long-term structure that promotes the subordination of women (Connell and Messerschmidt 2005). Men who successfully enact hegemonic masculinity are empowered by a system where they occupy most positions of authority, where "core cultural ideas about what is considered good, desirable, preferable, or normal are associated with how we think about men and masculinity" and "the focus [in a society] is primarily on men and what they do" (Johnson 2005:5-6, 10). The conflation of hegemonic masculinity with men makes it appear "natural" despite that "hegemonic masculinity remains a standard - whether reviled or revered - against which other masculinities compete or define themselves" (Nagel 1998:247). Rather than a power possessed and exerted by one group on another, discursive power is internalized, enacted, and policed by members of society so that it goes mostly unquestioned and produces meaningful identities that often become a source of self-pride (Foucault 1977).

One of the core tenets of hegemonic masculinity is the domination of women as well as subordinated and marginalized men and masculinities. Men (and women) who do not ascribe to heteronormative ideals often become the victims of physical, sexual, psychological, and symbolic violence 
given that "harassment begins when that power is challenged" (Bordo 1999:269). Physical domination of women and subjugated others is often represented by the phallus. "The phallus is master-signifier, and femininity is symbolically defined by lack" (Connell 1995:70). Drawing from the ancient Greeks who used the phallus as the essential image in the iconography of conquest, the phallus continues to be used in Western politics as a sign of domination (and masculinity). As Ducat $(2004: 2,150)$ argues, "while all anatomically intact males have a penis, no one has a phallus - the mythic, permanently erect archetypal monolith of masculine omnipotence." The "coveted signifier of masculine invulnerability and self-sufficiency is a fantasy, not an organ. Yet, the symbolic subtext of nearly every debate between and concerning male (and even some female) politicians is about who is the true possessor of that imagined trait."

The penis came to represent the phallus in the same manner that all dominant social groups justify their power and privileges: Men sought to claim "entitlement based on essential superiority, which is signified by some readily identifiable trait that is shared by all members of that group ... for men in a patriarchal order, the penis ... was and remains a visible signifier of essential difference. . . . It becomes the phallus" (Ducat 2004:246). While likening men to the phallus serves as a compliment or sign of respect, representing women in phallic terms is a means of highlighting their inappropriate behaviors, deviating from the "good woman" script that defines women as "caregiving, desirable but without desire, passive, submissive, self-deprecating, fragile, and in need of male protection" (Ducat 2004:116-17). Men without the phallus are often constructed as emasculated as they lack the ability to dominate, a core feature of hegemonic masculinity.

The power of the phallus is akin to the discursive practices and embodied behaviors associated with hegemonic masculinity that derives its meaning through contrast with femininities as well as subjugated and marginalized forms of masculinity such as gay men and men of color (Connell 1987). As a discursive construction, very few (if any) men actually embody hegemonic masculinity, but all men benefit to some extent from the equation of masculinity with power, intelligence, and control, something that Connell (1995:41) calls the "patriarchal dividend." Regimes of truth function not by enacting a repressive function upon its audience but rather through the establishment of a code that one is motivated to accept, abide by, and participate in to wield power (Foucault 1977). Therefore, as a dramaturgical accomplishment (Goffman 1959; West and Zimmerman 1987), masculinity - and gender more generally - is constructed and maintained as a symbolic ideal through interaction with other individuals and groups, often with those who are subordinated in the process. For example, in her study of adolescent masculinity, Pascoe (2012) documents how high school boys call other boys a "fag" or "faggot" as a means of policing each other's performances of masculinity. Masculinity requires maintaining difference from and dominance over other social groups by constructing these groups as less qualified, valuable, or desirable (Collins 2006; Pascoe 2012). As such, we might understand homophobia as "the fear that other men will unmask us, emasculate us, reveal to us and the world that we do not measure up, that we are not real men" and racism as the correlate, where men's skin color gets constructed as "suspect and they are assumed to be criminal" as a means of discrediting their humanity and accomplishments (Kimmel and Plante 2005:35; Collins 2006).

Hegemony, unlike other forms of power, convinces people to participate in their own oppression; as such, it requires consent of both the oppressors and the oppressed (Gramsci et al. 1971). Under such a formulation, power is not something possessed but rather is a "network of practices, institutions, and technologies that sustain positions of dominance and subordination in a particular domain" (Bordo 2003:167; Foucault 1977). Given this fact, hegemonic masculinity is a relational construct defined through a series of oppositional relationships with women, gay men, poor and working-class men, boys, and men of color. "Without these groups as ideological markers, hegemonic masculinity becomes meaningless. Each of these groups serves as an important social group for constructing the ideas of hegemonic white masculinity as well as actual social practices of dominance that maintain power relations that privilege elite white men" (Collins 2006:82). These groups are strategically fractured so that they enact oppression upon groups "below" them in the social hierarchy, deriving a sense of superiority despite the fact that all suffer from the existence of the hierarchy that privileges hegemonic masculinity above all else.

\section{Political Humor as Datum}

Given its ambivalent nature, humor is not often used as a source of serious academic scholarship. However, of all the forms of communication, humor is arguably one of the most reliant on cooperative participation between performer and audience. In laughing, we become connected with others who laugh with and at us, who "get" the joke. We recognize our shared perspectives: how we participate in but are also able to intellectually recognize the absurd. The punch line of the joke abruptly shifts the audience from "a previously understood narrative, to a very different world, thus creating tension among different understandings of the joke's narrative" (Tavory 2014:277). Humor works precisely because people share this tension and juggle multiple meanings collectively - thus producing a subversive insider identity (B. Anderson 1991; Critchley 2002; Herzfeld 1997) of those whose laughter has the potential to challenge the status quo or reify the very structures of oppression it seeks to dismantle (Smirnova 2014, 2017).

Similar to hegemonic masculinity, humor is strongly tied to a specific historical-cultural configuration. This is why jokes from another country or time period often fail to make 
us laugh. Humor often reveals the "public secret . . that which is generally known but cannot be articulated" (Taussig 1999:5). By bringing into focus the unseen, ignored, or repressed, humor can serve as an act of "everyday resistance" that stops "well short of collective outright defiance," but it can create solidarity and support through collective disapproval and critique (Scott 1990:29).

In the same motion of contesting power, people may inadvertently support the structures of domination that compel resistance at all (Bridges 2010; Hollander and Einwohner 2004). Acts of everyday resistance such as humor not only often go unnoticed, but laughter may be recognition of our own participation in the very structures that oppress us. Although citizens may come up with creative ways of separating words or phrases from their official meanings by manipulating texts and images to highlight the incongruities between the official projected image and the experienced everyday reality; in doing so, they reaffirm the power of current elites to define the vocabulary, signs, and symbols of that collectivity (Mbembe 2001), such as equating scripts of masculinity with presidential fitness.

During the 2016 election cycle, online, image-based humor was incredibly popular, in part because of how easily, quickly, and far it could be shared - thus integrating itself into cultures and collective identities. For example, of the content on the Breitbart News Facebook page, one of the most popular news sources among the politically far right in the United States, images and videos were overwhelmingly more popular than links to articles. Although images made up only 5 percent of Breitbart's total posts in 2016, they accounted for half of the page's most shared posts (Renner 2017). Similarly, of content posted to Twitter or Facebook, the most frequently shared posts included images (Ross 2014). According to a study of over 1 million posts from 30,000 Facebook users, images accounted for 75 percent of content posted to Facebook and resulted in an 87 percent interaction rate. In comparison, no other type of content posted (e.g., links, textbased statuses, videos) exceeded a 4 percent interaction rate. Similarly, in an analysis of over 2 million tweets, those that included an image were 35 percent more likely to be retweeted or shared (Rogers 2014). Research also indicates that people have substantially higher memory recall for text paired with images rather than text in isolation (Brady et al. 2008). This reflects a marked shift in the transmission of knowledge, where image-based, short-form, humorous communication travels much farther and more rapidly than traditional printbased media. In sum, memes, tweets, and political cartoons reach a broader audience than long-form print texts and by virtue of the sharing model, must reflect the perspectives of those who reproduce and engage this content.

In analyzing the 2016 election cycle with the guidance of literature on hegemonic masculinity, feminist perspectives of the body, and political humor, this study examines how humorous discourses often draw on gender scripts and tropes in political critique, thereby supporting a patriarchal system that privileges men over women and subjugated masculinities.

\section{Data and Methods}

The humor analyzed for this study comes from the three online sources: Facebook, Instagram, and Twitter. These are the three most popular social media platforms used by voting age U.S. adults (http://www.alexa.com/topsites/countries/ US). While the original source of the humor is often an external website, given that they become popularized and shared through social media platforms, the data were collected on these three sites.

In 2016, a majority of U.S. adults - 62 percent-accessed news on social media (Gottfriend and Shearer 2016). A national survey of 1,520 adults conducted between March 7 and April 4, 2016, found that nearly 8 in 10 online Americans (79 percent) use Facebook, a third use Instagram (32 percent), and a quarter use Twitter (24 percent). Taking into account that almost 9 in 10 Americans are online (M. Anderson and Perrin 2016), this means 68 percent of all U.S. adults are Facebook users, 28 percent use Instagram, and 21 percent use Twitter (Gottfried and Shearer 2016) and likely had some exposure to these types of political humor.

The three primary forms of humor analyzed for this study are political cartoons, tweets, and memes. Political cartoons have a long history, first appearing in pamphlets, then print newspapers, and now circulated online. They are often comprised of a drawing accompanied by a text-based caption or dialogue, and they are typically signed by the artist. A tweet is a post shared on Twitter. It may be text or image based, taking the form of either a single image frame with a caption or text-based comment under 140 characters in length. It is also connected to a Twitter "handle," a personal online identity of the user who originally posts (i.e., authored) or shares (i.e., cites) the tweet. The "meme" was first coined by Richard Dawkins as "a unit of cultural transmission or a unit of imitation." He used the term more broadly, referring to that which could be reproduced, such as DNA sequences, religious rituals, or musical melodies that have the potential to be disseminated widely and rapidly (Schreckinger 2017). The "Internet meme" is a more recent manifestation of this concept, referring specifically to an image, usually a photograph, with a clever caption that is easily shared on social media. It is a reproducible part of culture that can be slightly altered to build on an idea or apply a critique or perspective to a current event. The Internet meme is often created anonymously, reproduced and shared widely, then altered or refashioned and shared again (Renner 2017). Each of these three mediums - political cartoons, tweets, and memesenable people to share controversial or offensive memes without taking responsibility for their content, employing the same defense as they do with oral jokes- "It's just a joke" and "I didn't write it, I'm just sharing it." In such a way, they provide a window into the "public secret" (Taussig 1999). 
Table I. Humor Themes.

\begin{tabular}{lcc}
\hline Code & $N$ & Percentage \\
\hline Anti-Clinton & 109 & 45 \\
Clinton as inappropriately & 46 & $19(42)$ \\
$\quad$ masculine & & \\
Anti-Trump & 115 & 48 \\
Trump as inappropriately & 58 & $24(50)$ \\
$\quad$ masculine & & 7 \\
Anti-Clinton + Trump & 16 & 23 \\
Sex/sexuality & 56 & 22 \\
Male or female bodies & 53 & 19 \\
Misogyny & 45 & 18 \\
Dishonesty & 42 & 17 \\
Family & 40 & 15 \\
Intelligence/mental health & 36 & 14 \\
Race(ism) & 33 & 13 \\
Violence & 32 & 10 \\
Strength/control & 25 & 10 \\
Weakness & 24 & \\
\hline
\end{tabular}

Note: Percentage of the subsample of memes about Trump and memes about Clinton are shown in parentheses.

The memes, tweets, and political cartoons in this study were analyzed using a broad content analysis to code for general themes in conjunction with critical discourse analysis (CDA) to analyze the relationship between text and context. On these three sites-Facebook, Instagram, and Twitter-humor was coded and analyzed based on explicit searches for the following terms as either separate words or combined as hashtags (\#): 2016 presidential election, (anti-) Hillary Clinton, Crooked Hillary, Hillary For Prison, Basket of Deplorables, Not with her, Hitlary, Nasty Woman, Bad Hombres, (anti-) Donald Trump, Dump Trump, Drumpf, Fuck Trump, and Grab Em by the Pussy cartoons, memes, and tweets that were frequently shared, liked, retweeted, or discussed through comments. This collection is based on posts that were dated between February 25, 2016, and November 9, 2017. To be included in the sample, the Facebook or Instagram post or the Twitter tweet needed to be either liked or shared at least 100 times as a sign of salience and popularity within the cultural discourse.

Using an abductive approach (Timmermans and Tavory 2012), humorous posts on the three social media platformsFacebook, Instagram, and Twitter-were theoretically sampled using a "constant comparative method" to establish whether emergent themes were "clearly indicated by data, and do they explain, predict, and interpret anything of significance" (Glaser and Strauss 1967:91). Instead of a purely deductive method that seeks to confirm theories and a purely inductive method that is not guided by theory, the abductive approach allows for the development of theory (inductive) that is produced by "surprising" and "puzzling" data that emerged through a theoretically informed design and coding scheme (deductive). Successful qualitative research requires one's awareness of and attention to one's own positionality (Collins 1992) and situatedness (Clarke 2003, 2005) and how this might impact what one sees or deems meaningful. This was noteworthy in the attempt to create a sample that was balanced in terms of anti-Clinton and anti-Trump humor as well as representative of humor that was not found humorous to the author.

After compiling a sample of 342 cartoons, tweets, and memes, it was determined the analysis had reached a point of "saturation"-where unfamiliar images no longer revealed new or divergent themes but rather reiterated and reaffirmed the same narrative and discursive patterns of images collected thus far (Clarke 2003, 2005; Luker 2008). A significant proportion of the memes in the sample had been created by multiple artists, offering the same critique or "punchline" but with slightly altered imagery, words, or font. While some iterations offered different critiques, most were variants on the same theme and therefore coded only once. Many of these images or jokes have long histories dating back to the 2008 primary election between Clinton and Obama or Bill Clinton's presidency. This is similar to Dundes and Pagter's (1991) analysis of Persian Gulf War folklore that drew from and built on a long legacy of phallic, racialized political cartoons often presenting "new" commentary that was often a heavily recycled joke that entered the imaginary decades ago. While this genealogy of humor cycles offers rich data for analysis, it is outside the scope of this work, and therefore each joke is accepted "as is" without deconstructing its origin.

This sample was then pared down to 240 unique memes, tweets, and political cartoons for analysis. Of this sample, 115 were anti-Trump, 109 anti-Clinton, and 16 critical of both. They were coded for broad themes (Table 1), including: sex or sexuality ( 23 percent), the body (size of hands, body, penis for men, size of breasts, thighs, and other objectification of the body for women) (22 percent), misogyny (physical or sexual violence against women) (19 percent), dishonesty (18 percent), family (humor targeting family members and/or Clinton's or Trump's role in the family) (17 percent), intelligence/stupidity/sanity (15 percent), race(ism) (14 percent), violence (13 percent), strength/control (10 percent), and weakness (10 percent). These themes coalesced in two common configurations: (1) humor attacking Hillary for being inappropriately masculine (domineering other men) and inappropriately feminine (an inadequately sexually desirable body and overly aggressive) (46/109 jokes about Hillary, or 42 percent) and (2) humor attacking Trump for being inappropriately masculine in terms of his lack of phallus (small hands, small stature), femininity, sexuality, and lack of control (58/115 jokes about Trump, or 50 percent).

Like all qualitative work, it is impossible to know if the jokes analyzed are truly representative of the entire online population, and it is impossible to know how the person who created the political humor or the audience who liked or shared it interpreted its contents. However, with a focus on the relationship between text and context, it is possible to 


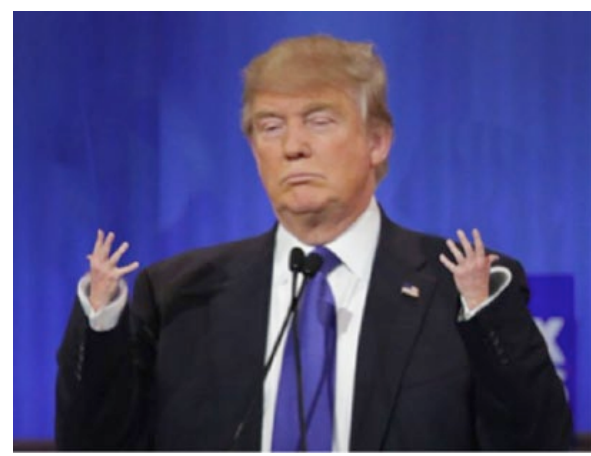

Figure I. Trump with "small hands."

Source: JeremiahWarren.com. (Meme based on an original photo by Chip Somodevilla, Getty Images)

construct the outline of an emergent ideological framework. While some studies focus more on the people who create and participate in these communities, others, like this one, focus on the cultural productions as reflective of shared values, perspectives, and interpretations of the social world.

The images were analyzed using CDA. CDA is both a method and a theory that focuses on "the way social power abuse, dominance, and inequality are enacted, reproduced, and resisted by text and talk in the social and political context" (Van Dijk 2001:352). The focus of CDA is on discourse at two different levels - the microanalysis of the particular "token" text dissected and the macro level - in terms of connecting that particular text to a larger web of meaning. In this case, this involves contextualizing the "joke" within relevant cultural and political events that help the reader understand the multiple meanings and consequences of the particular joke. CDA endeavors to understand how discourse connects the micro and the macro in terms of how members are constructed as part of the group as well as how the actions of these members construct larger social processes (Van Dijk 1997, 2008).

CDA is often (at least in part) politically motivated and therefore goes beyond simple descriptions of the world to delineate relationships of injustice and inequality that operate through text and talk. As such, "critical discourse analysts take explicit position, and thus want to understand, expose, and ultimately resist social inequality" (Van Dijk 2001:352). CDA embraces a feminist situated perspective by trying to understand how discourses construct bodies and collectivities in different (and unequal) ways while simultaneously recognizing how scholarship is sociopolitically "situated" regardless of our intentions or efforts to combat it.

\section{Findings}

\section{"Look at These Hands. Are They Small Hands?" Bodies, Virility, and the Phallus}

The 2016 U.S. presidential race began with contentious primary elections in both the Republican and Democratic
Parties. The Republican Party presidential primaries began with 17 candidates vying for the Republican nomination, which resulted in a tumultuous and combative race. Many insults were exchanged over the 13 months between the candidates and their supporting constituents. While not always explicit, many of these insults were coded in politics of masculinity.

A notable example of how gender was a central feature of the primary race began when Donald Trump taunted Florida Senator Marco Rubio by calling him "Little Marco." Upset by this diminutive, Rubio conceded that Trump was taller than him but rebutted by suggesting that Trump had small hands for his height. Specifically, during a political rally in Roanoke, Virginia, Rubio argued that Trump is "like 6'2 which is why I don't understand why his hands are the size of someone who is 5 ' $2 \ldots$ and you know what they say about guys with small hands," he said with a smile, prompting laughter from the crowd, "You can't trust them!"

In response to Rubio's accusation, Trump took the 11th GOP debate to defend himself. Holding up his hands for the audience and cameras, he remarked, "Look at those hands, are they small hands? And, [Rubio] referred to my hands - 'if they're small, something else must be small.' I guarantee you there's no problem. I guarantee.” The next day, the front page of CNN's website read: "Donald Trump Defends Size of His Penis" (Krieg 2016). Rubio's comment and Trump's rebuttal became the focus of many online tweets, memes, and cartoons, emphasizing Trump's small hands as a means of attacking his genitalia and presumably his masculinity given that "in American folklore, the size of a man's hands and feet are thought to symbolize the size of his penis, the size of which itself is a symbol of one's virility and masculinity" (Pascoe 2017:123; Dundes and Pagter 1991). Photoshopped images of Trump with disproportionately small hands, such as the one pictured in Figure 1, can be interpreted as intended to attack the size of his penis (and phallus).

The exchange between Rubio and Trump as well as the resultant humor supports Ducat's (2004:150) assertion that the phallus, the "symbolic subtext of nearly every debate between and concerning male (and even some female) politician is about who is the true possessor" of the "coveted signifier of masculine invulnerability and self-sufficiency." While the penis itself is often deflated, the symbolism of the erect and dominant phallus is associated with control and dominance.

Another meme (Figure 2) presents a hypothetical dialogue between former President Obama and Vice President Joseph Biden about Trump's small hands.

While the meme in Figure 2 questions Trump's genitalia, it is more focused on how he will "measure up" in the White House in terms of masculinity and competence. While the humor may intend to symbolically belittle Trump, by focusing on the phallus as a measure of qualification, these critiques unintentionally reaffirm the centrality of essentialist masculinity to presidential ideals (Connell 1995). Though 


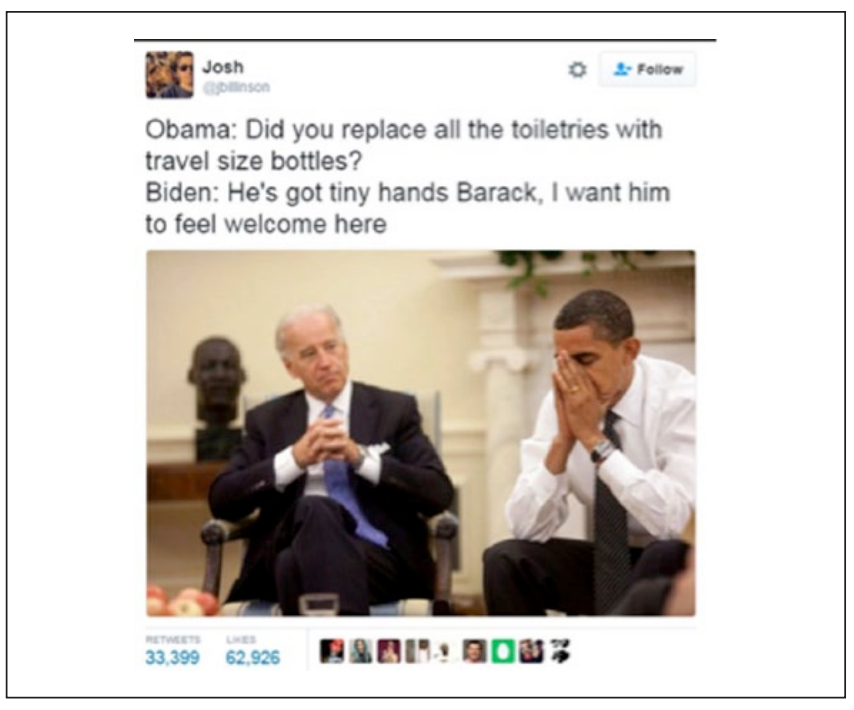

Figure 2. Obama and Biden discuss Trump's "tiny hands." Source: @jbillinson on Twitter.

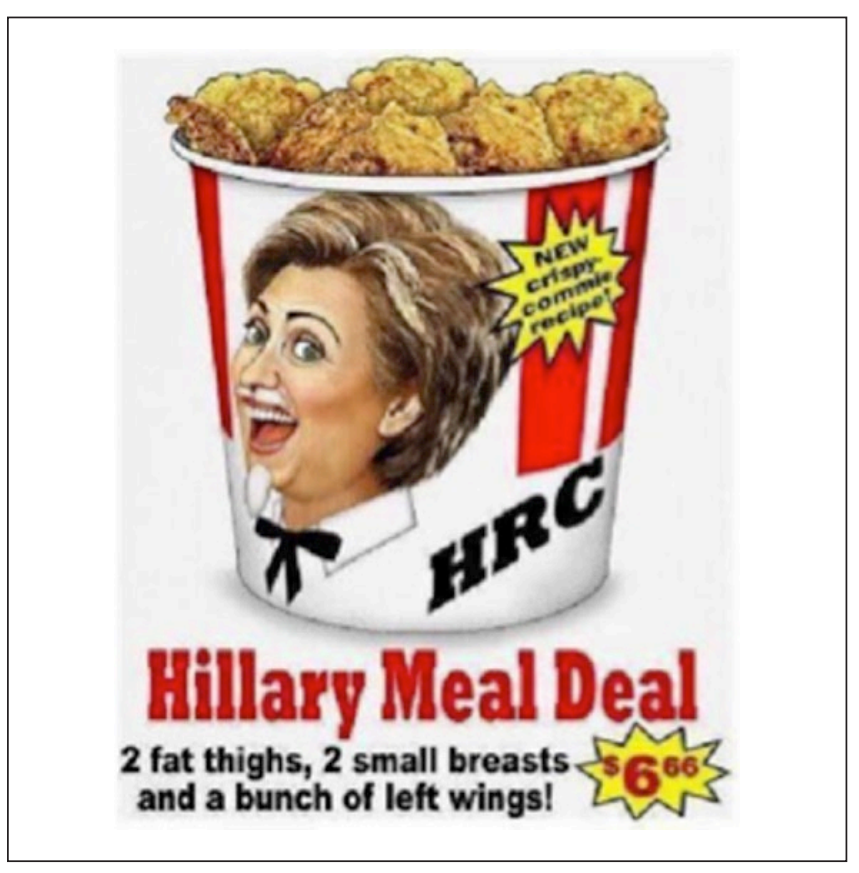

Figure 3. Clinton as a bucket of deficiently feminine body parts. Source: @CSLewisFan on Reddit.

masculinity and femininity are not reducible to male and female bodies, bodies are "the vehicles through which we express gendered selves; they are also the matter through which social norms are made concrete" (Pascoe 2012:12). As such, the relentless attention paid to both the male and female body in such political humor reifies the association between domination, masculinity, and men and subordination, femininity, and women.

As a parallel, Hillary Clinton was criticized for being fat, unfeminine, and undesirable, criteria for the successful accomplishment of womanhood in the United States. Women seeking positions of authority in a patriarchy are often silenced or discounted by being deemed too masculine, insufficiently feminine, or through the process of objectification and othering. As Bordo (2003:166) argues, "female bodies become docile bodies - bodies whose forces and energies are habituated to external regulation, subjugation, transformation, 'improvement." By transforming women from active subjects into passive objects, they are dehumanized and reduced to sexual conquests. The cartoon in Figure 3 depicts Clinton as a bucket of fried chicken, decomposed into different body parts and ideologies (e.g., left wings). The price of $\$ 6.66$ implies that she is the devil, as 666 is the "Number of the Beast." This term comes from the Christian Bible meaning the anti-Christ or anti-Christian values. Therefore, it implies that Clinton rejects Christian values, potentially as a woman who is not fulfilling her proper feminine duties as a homemaker, or by assuming a masculine role, she must be controlled by the masculine devil.

By criticizing Clinton's body parts, this narrative both reifies her construction as a passive, primitive representation (McClintock 1995:359) and also criticizes that representation by calling her thighs fat, her breasts small, and that her ideology is a "crispy commie." Women's bodies are cultural texts that are measured in terms of their ability to emulate a particular cultural ideal of beauty - white, thin, big breasts - and any deviation from this idea renders the body undesirable and without value (Bordo 2003). As such, this cartoon attacks her ideological, moral, and religious worth. Further, by reducing her to a bucket of body parts, she is sexually objectified and dismissed outright as an undesirable woman in a world where women's value is synonymous with her body's sexual desirability to be consumed like a bucket of fried chicken.

Hillary Clinton was accused of being too masculine and diverging from the feminine body ideal but also for lacking sexual appeal. For women to have "the phallus," they must be desirable to the men in control (Bordo 1999; Ducat 2004). For example, a number of memes referenced Hillary's husband, Bill Clinton, and his infidelity to her as a sign of her inability to "get the job done" sexually or in office. Bill Clinton served as the 42nd U.S. president between 1992 and 2000. During his time in office, it was discovered that he was engaged in a sexual relationship with one of his interns, 22-year-old Monica Lewinsky. Hillary remained by Bill's side during the accusations. Although the infidelity occurred between Bill and Monica, her husband's infidelity was treated as a sign of her failure as a wife and as a woman (see Figure 4).

In the aftermath of the Lewinsky scandal, Bill Clinton's popularity as president and Hillary Clinton's as first lady skyrocketed. In fact, a 1998 U.S. Gallup poll conducted after the scandal broke reported that Bill Clinton was the most admired man in the world. Sociologists attributed this shift as reflecting the Clintons' successful accomplishment of masculinity and 


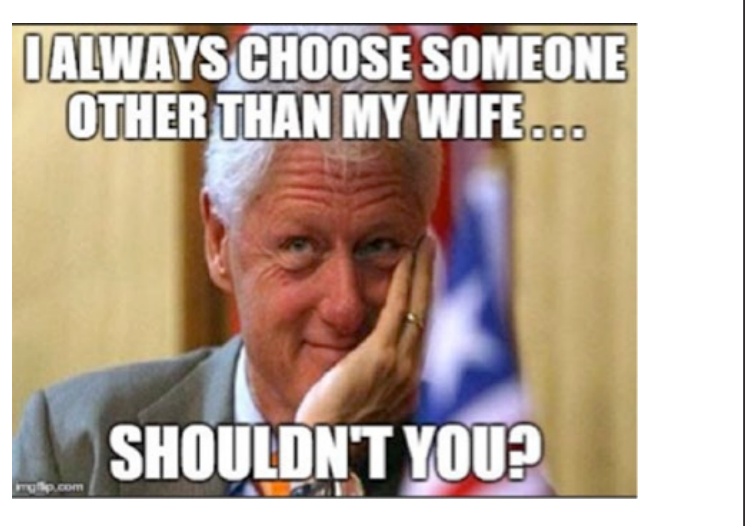

Figure 4. A reminder of Bill Clinton's infidelity. Source: imglip.com.

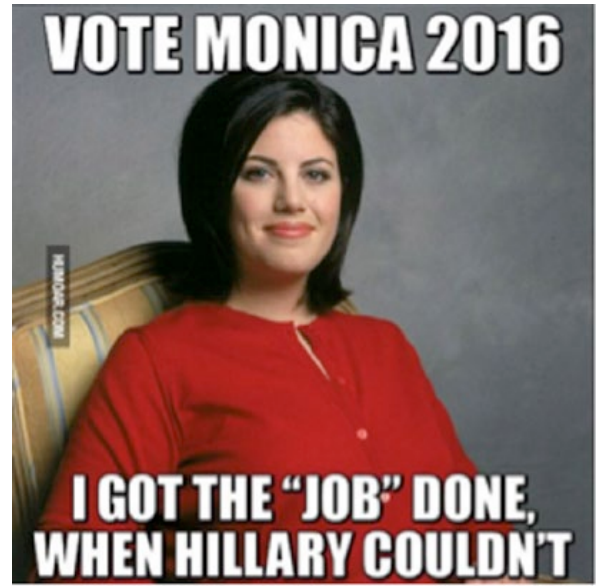

Figure 5. Challenging Hillary Clinton as a woman, lover, and presidential candidate.

Source: www.humoar.com. (Meme based on an original photo by Robert Hanashiro, USA Today)

femininity, where Bill became a "walking erection" and Hillary successfully adopted "the more "feminine' role of wounded woman standing by her man" (Messner 2007:473; Ducat 2004:135). However, once Hillary decided to run for office herself, Bill was forced to flip the script from "stand by your man" to "stand by your woman," and their popularity and likeability plummeted (Doyle 2016). Given that "a woman's political relation to the nation [has historically been] submerged as a social relation to a man through marriage" (McClintock 1995:358), the woman who puts her career first, particularly in the field of politics proper, necessarily challenges prescribed gendered behavior in both public and private spheres.

This reflects the gender mythology that equates masculinity with creativity and change and femininity with stability and continuity (McClintock 1995). National ideology often draws on the same myths and ideologies as the traditional family

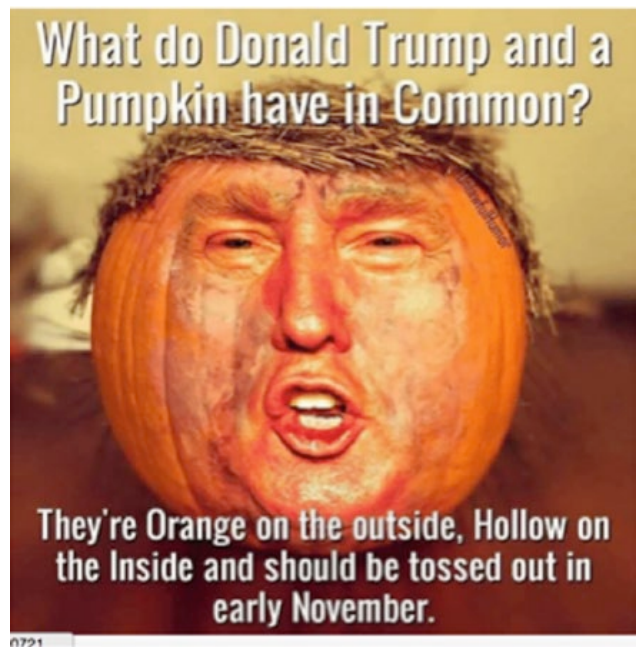

Figure 6. Trump as pumpkin critiques vanity and intelligence. Source: @UnlawfulHumor on Twitter.

structure where men are defined as breadwinners and women as caregivers and homemakers (Collins 1998; McClintock 1995), implementing a "family image [that] figure[s] hierarchy within unity" (McClintock 1995:45). According to traditional family scripts, men defend the family and nation while women protect the honor of the family and nation and "women's shame is the family's shame, the nation's shame, the man's shame" (Nagel 1998:254). As such, humor critiquing Hillary's success focused on her "shame" or "failure" to sexually satisfy her husband and assumedly prevent the affair (Figure 5).

As symbolic mothers of the nation, there is a simultaneous emphasis on purity and sexuality; women must be faithful and chaste but also sexually desirable as they reflect male honor. As Frye (1983) pointed out long ago, women in the United States "are in a bind where neither sexual activity nor sexual inactivity is alright." If she is married and her husband strays, this should be taken as a sign of her inadequacy as a woman to both satisfy her husband and defend his (and the nation's) honor.

Although research indicates that more attractive candidates fare better in elections (Little et al. 2012), Trump was regularly made fun of for his tan skin and coiffed hair, humor implying that caring about one's appearance undermines a successful accomplishment of hegemonic masculinity (Figure 6).

Other jokes fixated on his hair and his styling practices (Figure 7).

As women's value is traditionally constructed as derived from their appearance, the comparison between Trump and a passive object (pumpkin) concerned with vanity was likely intended to diminish his projected sense of control and dominance. However, this line of attack may have not accomplished what it intended, in part because of how upper-class men "do" masculinity differently. For example, while Barber 


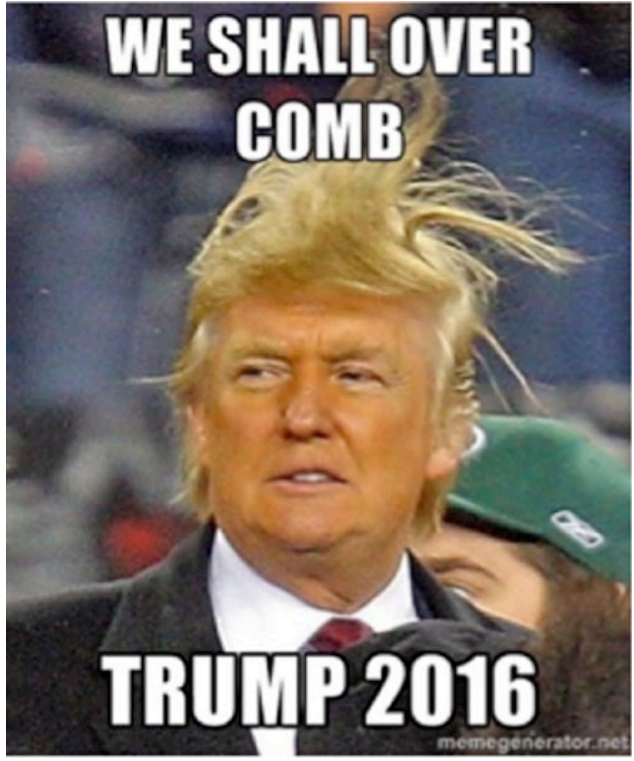

Figure 7. Trump's hair as a symbol of vanity and inauthenticity. Source: http://freenj.blogspot.com/2015/07/we-shall-over-comb.html.

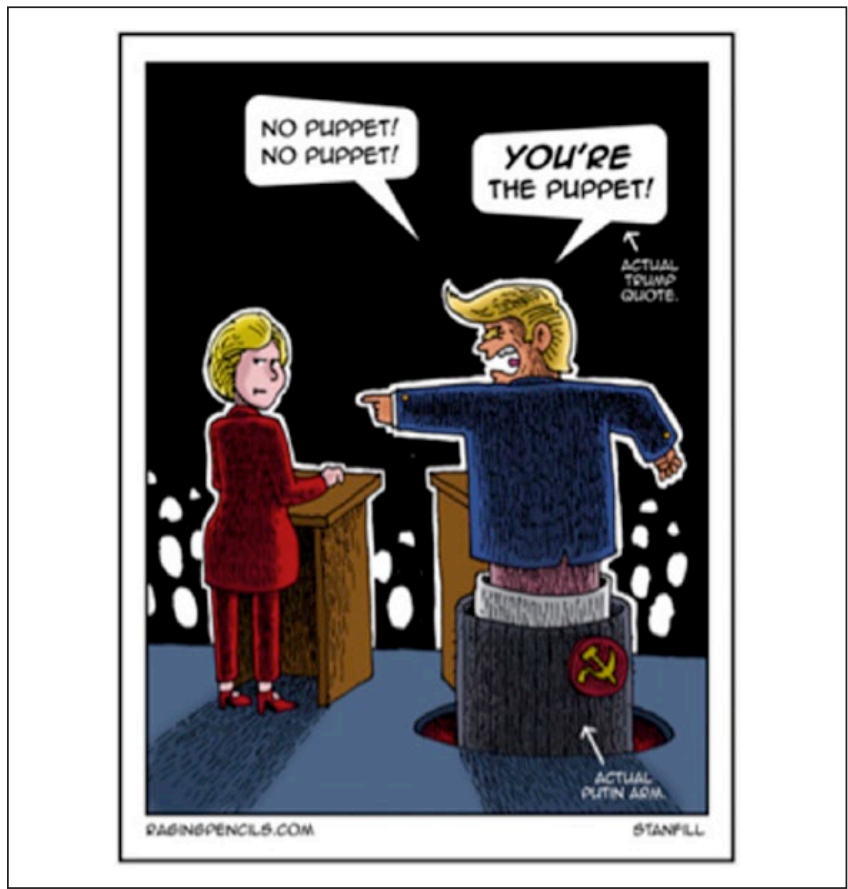

Figure 8. Trump accused of being a puppet under control of Vladimir Putin.

Source: Ragingpencils.com.

(2008) found that men who frequented hair salons as opposed to barbershops did experience a threat their masculinity, "since, as men, their sense of self-worth is not supposed to be tied to how they look . . . to counteract this potential threat, the men claim they do not want to look stylish for themselves; rather, they need to look good to succeed professionally" (470). Donald Trump regularly used this type of defense, going on record saying that: "I'm the most successful person ever to run for the presidency, by far. Nobody's ever been more successful than me. I'm the most successful person ever to run. Ross Perot isn't successful like me. Romney-I have a Gucci store that's worth more than Romney" (Greenhouse 2015). Barber (2008:472) argues that men who receive salon hair care appropriate a "professional-class whiteness" by "doing difference" (West and Fenstermaker 1995 ) in such a way that distinguishes themselves from nonwhites, women, as well as the poor and working-class.

\section{Puppets and Nasty Women: Masculinity as Control, Femininity as Submission}

A puppet is an object that is exclusively controlled by someone else; accordingly, it represents the opposite of masculinity in a patriarchy where men can only be men when they are in control. Being accused of being a puppet implies that any power one appears to have originates from someone else. In the third and final presidential debate of the 2016 election, Democratic nominee Hillary Clinton accused Republican nominee Donald Trump of being a "puppet" for Russia and its president, Vladimir Putin, a claim to which Trump vehemently disagreed, retorting "No puppet! No puppet! You're the puppet!" Many tweets and memes used this exchange as a source of humor (Figure 8).

By accusing Trump of being Vladimir Putin's puppet, Clinton implied that Trump's relationship with the Russian president was not based on equality and mutual respect but rather that Putin was using Trump to further his own national interests. In Figure 8, the size of Putin's hand in relation to Trump's body (not to mention Trump's disproportionately small hands) again draws on these essentialist associations between masculinity, size, and dominance as well as the semiotic and normative definitions of masculinity, which could emasculate Trump through his association with passivity and lack of control, characteristically feminine traits. Writing in 1977, Nancy Henley described how men often used women as "puppets" or "toys" to use in their own performances of masculinity: "Males are the movers and the powerful in life, females the puppets" (p. 150). By constructing Putin as the man and Trump as the puppet, Clinton emasculated Trump in terms of his dominance over women but also potentially in terms of his sexuality (to be discussed in the following section). In response to Clinton's accusations, Trump engaged in a number of discursive strategies to undermine Clinton, each of which drew on a patriarchal gender structure that reaffirmed his superior position as a man and Clinton's subordinate one as a woman.

During the third presidential debate, Trump called Clinton a "nasty woman" after she accused him of evading tax payments. Trump's insult was immediately picked up by the Twittersphere, including Clinton's own Twitter feed that 


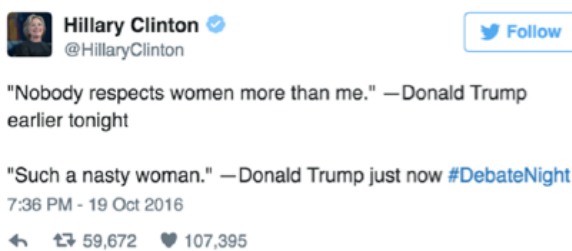

Figure 9. A tweet from Clinton's account. Source: @HillaryClinton on Twitter.

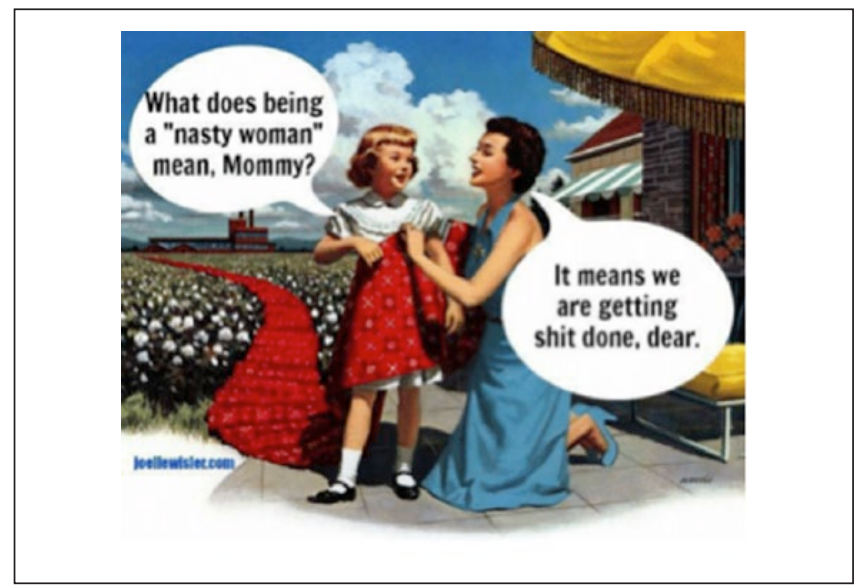

Figure 10. Redefining "nasty woman" into a feminist ideal. Source: www.joellewisler.com.

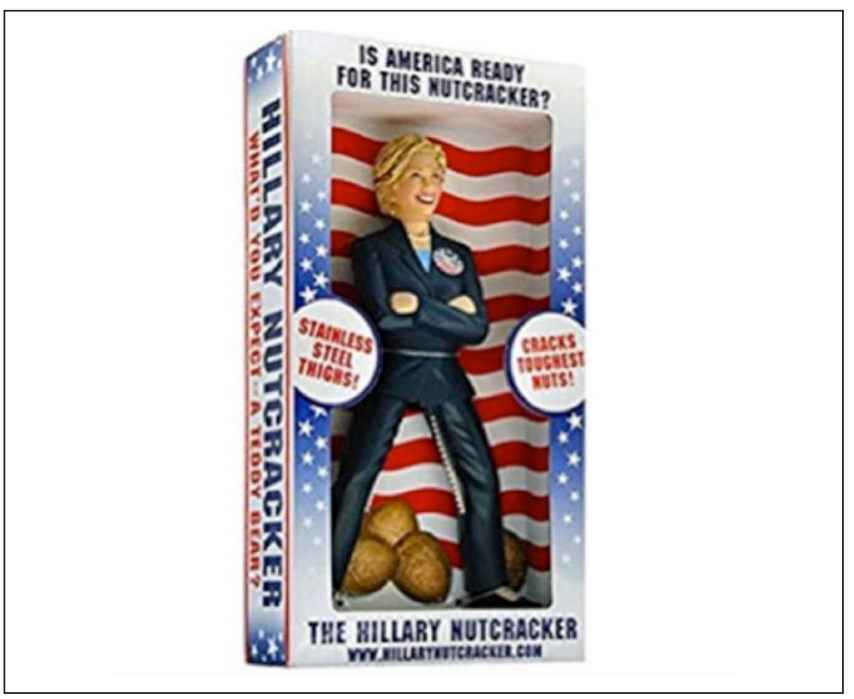

Figure I I. Implication that feminine power "cracks" men's "nuts." Source: Amazon.com.

challenged Trump's insistence that he respected women (Figure 9).

Clinton's tweet highlighted the contradiction between two statements, the first boasting of respect and the second demonstrating disrespect. In response to this exchange, the term Nasty Woman became a rallying cry for Clinton supporters online, who used it as synonymous with being a feminist or a strong, powerful, and successful woman. Figure 10 illustrates this redefinition.

Despite this concerted effort to redefine the insult, during the presidential race, such name-calling diminished Clinton's qualifications and abilities by penalizing and policing nonconforming gender practices. While women can also "do" masculinity, masculinity is often seen as only appropriate and advantageous to men who enact it rather than women (Bordo 2017; Nagel 1998). When women do seek to compete in fields that reward performances of masculinity, they face the "double bind" of having to be appropriately feminine while still proving themselves competent according to criteria that is culturally coded as masculine (Bordo 2003, 2017).

When Clinton attempted to play by the same rules as her predecessors, she was often criticized for being too masculine. "Male leaders can be tough and (appropriately) masculine. Female leaders can either be tough or (appropriately) feminine. Pulling off both at the same time is not impossible, but it is tricky terrain to navigate" (Sheeler and Anderson 2013:151). In response, women who attempt to walk this tightrope experience accusations of being "too feminine," also known as weak and unfit for presidency, or "too masculine," too domineering, unlikable, and inauthentic. For example, one line of merchandise constructed Clinton as a "nutcracker," a woman who "busts" men's "nuts," and was shared on various social media platforms as a joke (Figure 11).

As we see from the merchandise in Figure 11, Hillary Clinton was criticized for playing by the same rules that advantaged the other candidates because of her gender. The humor drawing on the nutcracker imagery reflects a long history of folklore warning men to be wary of "vagina with teeth." While some stories involve the literal penis being cut off by the vagina, many others involve men "being emasculated in less literal ways-being eaten, poisoned, infected with diseases, rendered impotent, turned into women" (Ducat 2004:119). It is important to note that

the fundamental fear in castration anxiety is not so much about physical injury per se but an injury that feminizes - a fate that, in some men's eyes, could just as easily result from feeling dependent on ("out of a limb") or controlled by ("pussywhipped") a woman, as it could be from vaginal scissors. (Ducat 2004:116)

Clinton was constructed as this "vagina with teeth" both figuratively and literally in her quest for power and control through the presidential office.

At a rally, Donald Trump tells his audience, "Now you tell me she looks presidential, folks. I look presidential" (Colvin 2016). This comment speaks to the fact that all former U.S. presidents were men and all but one (Barack Obama) were white (not to mention cisgender, heterosexual, middle or upper class, and Christian), as is highlighted by the tweet in Figure 12. 


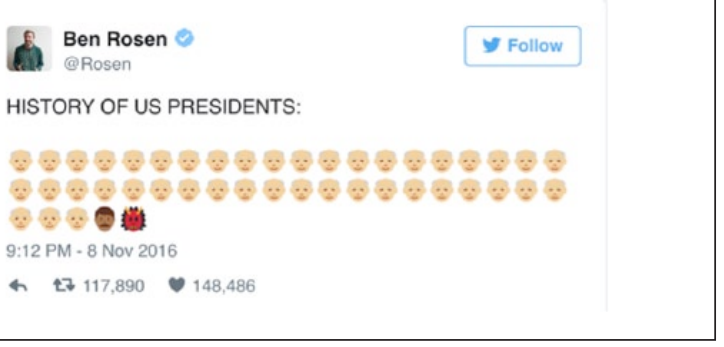

Figure I2. The history of US presidents, Trump as Satan. Source: @Rosen on Twitter.

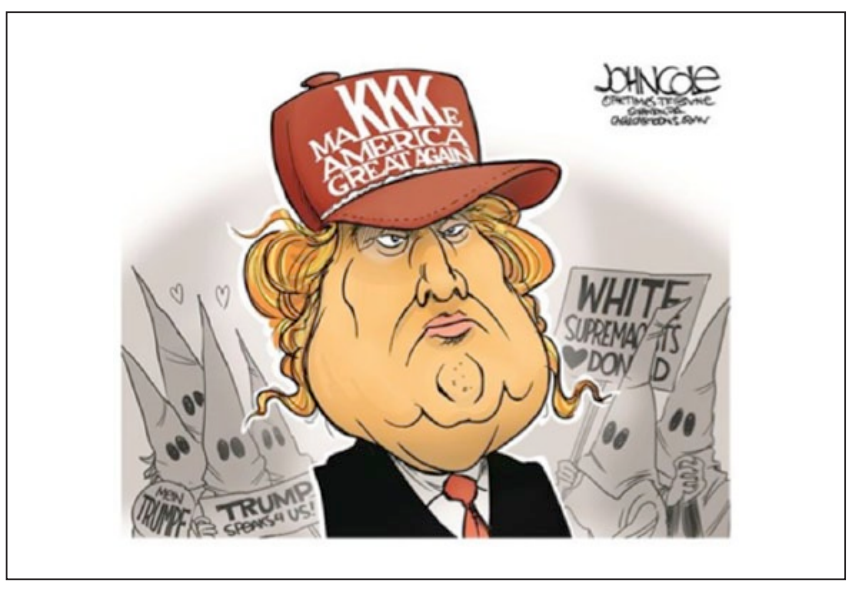

Figure 13. Trump and white supremacist values. Source: John Cole at the Times-Tribune. (Scranton, PA; http:// timestribuneblogs.com/uncategorized/man-of-the-white-people/)

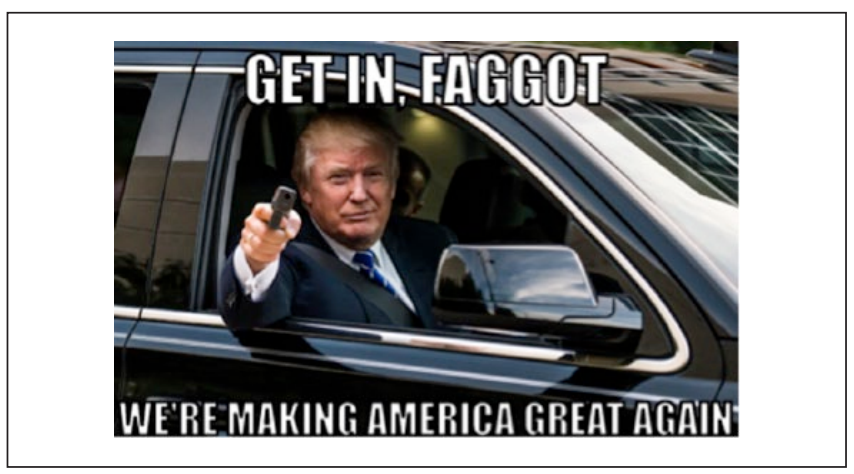

Figure I4. Trump, toxic masculinity, and homophobia. Source: https://chiefdonaldtrump.com/get-in-faggot-donald-trump-meme/.

This tweet initially corroborated Trump's statement of who looks "presidential," but then the "punch line" shifts the depiction of Donald Trump from just another white man to the Devil, distinguishing Trump from his predecessors in a negative - however still powerful - way. This humor draws attention to the racial and gender configurations of the historical presidency but does little to challenge it. While the devil is the definition of evil, as the primary opponent to
God, he is still coded as powerful and masculine (Leeming 2005). Both Clinton and Trump were defined as the Devil in different cycles of humor, a biblical reference that reifies yet another patriarchal structure- the Church.

\section{"Bad Hombres": Hegemonic, Subjugated, and Marginalized Masculinities}

Masculinity is defined by dominance over women, but equally as much it is defined by dominance over other men (Pascoe 2017). Being a man is about not being a woman, but it is also about "distancing from masculine 'countertypes', whether racial ... [or] sexual—being a man is not acting 'feminine' and/or not being a homosexual" (Connell 1987:186; Nagel 1998:246). Trump's masculinity was protected in part by many of his supporters who actively engaged in sexist, homophobic, or racist banter (Frej 2016). Many argued that Trump's campaign itself was racist and homophobic (Figure 13).

Figure 13 draws connections between Trump's "Make America Great Again" and the white supremacist group, the $\mathrm{Ku}$ Klux Klan (KKK), who wears white hoods and sheets when lynching Black Americans, Jews, the LGBTQ community, and other marginalized social groups. As Hochschild (2016:229) argued, "Make America Great Again" translated to "Make men great again too, both fist-pounding, gun-toting guy-guys and high-flying entrepreneurs. To white, native born, heterosexual men he offered a solution to the dilemma they had long faced as the 'left behinds' of the 1960s and 1970s celebration of other identities."

The image of Donald Trump as supported by white supremacist men implies that Trump's policies and rhetoric supported their interests at the expense of others' well-being. Trump's endorsement by the Crusader, the KKK's official newspaper, in addition to David Duke, a longtime proponent and supporter of the KKK, offers evidence to support this claim (Holley 2016). The meme in Figure 14 offers a similar perspective.

The "fag discourse" (Pascoe 2012) employed in Figure 14 reflects masculinity politics in action by implying that those who don't vote for Trump are "sissies," "fags," or "without balls." Associating with and voting for Trump thus becomes coded as an act of masculinity - not voting for him reflects one's lack of masculinity or brotherhood (Bird 1996). Further, the fact that Trump is holding the viewer at gunpoint highlights the coercive power of hegemonic white masculinity that forces people to conform lest they suffer ridicule, exclusion, and/or violence (Stroud 2012).

The "fag" epithet challenges one's masculinity and honor (Pascoe 2012); however, accusing Trump of groping or sexually assaulting women did not effectively emasculate him, potentially reflecting the hegemony of a rape culture (Hlavka 2014; Pascoe and Hollander 2016). One of the biggest scandals of the 2016 election cycle involved a conversation between Donald Trump and Access Hollywood host Billy Bush that was 


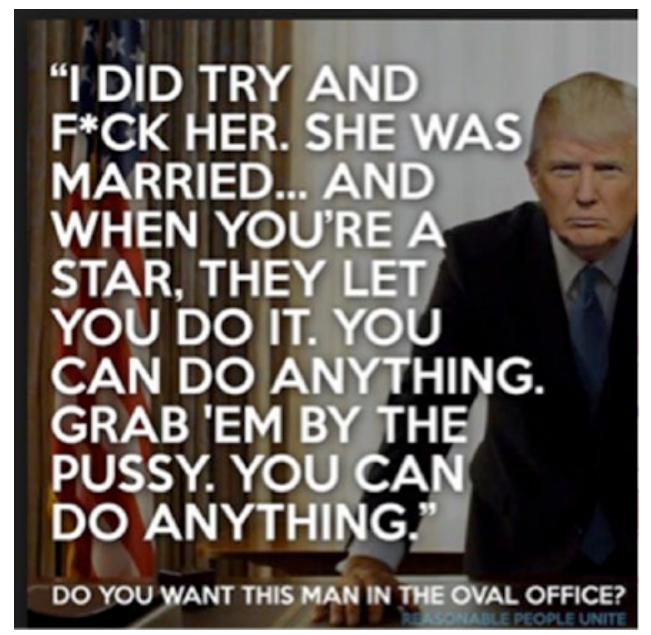

Figure 15. Quote from Access Hollywood tape. Source: Reasonable People Unite.

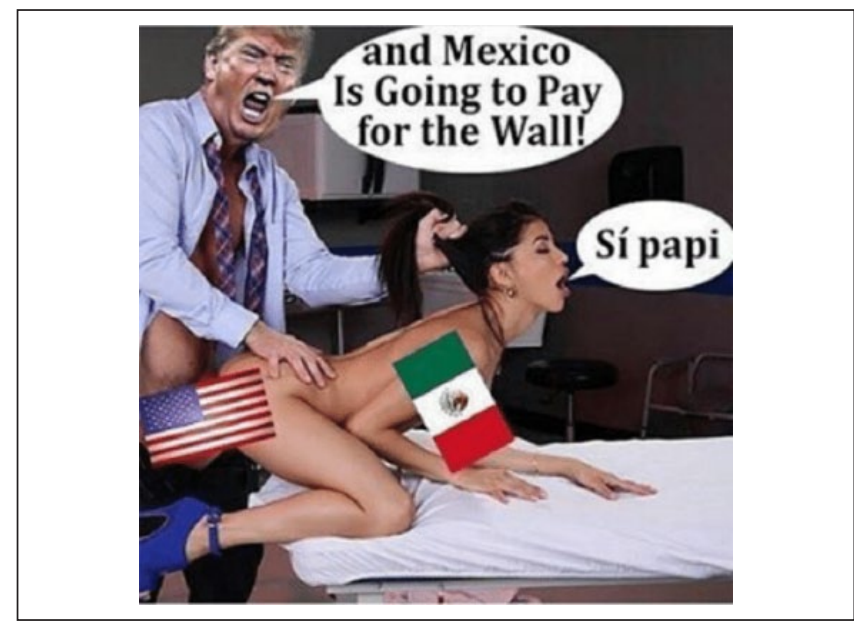

Figure 16. Violence and domination of Mexico.

Source: https://onsizzle.com/i/and-mexico-s-is-going-to-pay-for-thewall-4827II.

caught on tape. In a 2005 video, Donald Trump brags in vulgar terms about kissing, groping, and trying to have sex with women. In the conversation, Trump refers to women as "them," "pussy," and "bitch," linguistic strategies that dehumanize, sexualize, and objectify women (Bird 1996; Kleinman, Ezzell, and Frost 2009). One excerpt of the taped conversation that was transformed into a meme appears in Figure 15.

Figure 15 illustrates how the objectification of women, particularly among other men, helps men maintain a position of superiority and control (Bird 1996; Pascoe 2012). In the dialogue, Trump asserts his dominant masculine identity through the sexual objectification of women, emotional detachment of the pursuit, and competitive language of "when you're a star, they let you do it. You can do anything." While many Republicans initially denounced Trump and moved to distance themselves from him after the tape was released, over time, the story failed to define Trump as a rapist or unmasculine. Although "sexual assault remains widespread, being identified as a rapist has come to be seen, at least in some contexts, as unmasculine. However, this change coexists with the fact that dominance, especially sexual dominance, continues to be a central component of Western masculinity" (Pascoe and Hollander 2016:74). In this case, Trump's mobilization of sexual assault in his performance of masculinity appears to have overpowered the narrative of the rapist, in part because of his language that "they let you do it. You can do anything" implies that "he is desirable enough that he has no need to use force to obtain access to girls' bodies" (Pascoe and Hollander 2016:72).

This bravado, particularly in regard to sexual assault, was taken up in other online humor. For example, in reaction to Trump's assertion that he "will build a great, great wall on our southern border, and I will make Mexico pay for that wall," memes and tweets emerged from both sides of the political spectrum. For example, Figure 16 uses images of rape as means of critiquing Trump's promise.

In Figure 16, Donald Trump is not only violently penetrating a Mexican woman from behind while pulling her hair, but he is also demanding that she pay for it. In doing so, he draws from a historical colonial discourse colored by national chauvinism and entitlement of (white) Western expansion. The phallus imagery returns as symbol of power as "it is better to be a 'fucker' than 'fucked over,' better to be the one capable of intrusive control and sadistic aggression than to be "on the receiving end' (to use an appropriately anal metaphor)" (Ducat 2004:139). While powerful men are expected to have control over their penises (as opposed to being driven by lust), the erect penis symbolizes the phallus of domination.

Race and class are central to hegemonic masculinity in that outgroups are needed to construct and maintain the boundaries around a centered position (Connell and Messerschmidt 2005). Further, the "use of masculine imagery of rape, penetration and sexual conquest to depict military weaponry and offensives" is common in patriarchal societies (Nagel 1998:258).

Hegemonic masculinity exclusively privileges one specific configuration of gender, race, sexuality, and class: the white, wealthy, Western, Christian, cisgender, straight male over "others." To maintain this privileged position, gender narratives may construct men who do not ascribe to this prototype as feminine or flawed. For example, in a debate with Clinton, Trump constructed nonwhite men as criminals and enemies of the state:

One of my first acts [as president] will be to get all of the drug lords, all of the bad ones, we have some bad bad people in this country that have to go out. We're going to get them out. We're going to secure the border, and once the border is secured at a later date, we'll make a determination as to the rest, but we have some bad hombres here and we're going to get them out. (Schwartz, 2016)

Using a mock-Spanish term for men, a mispronounced hombres, Trump implied that the "all of the drug lords, all of the bad ones" are Spanish speakers, specifically Mexican men 


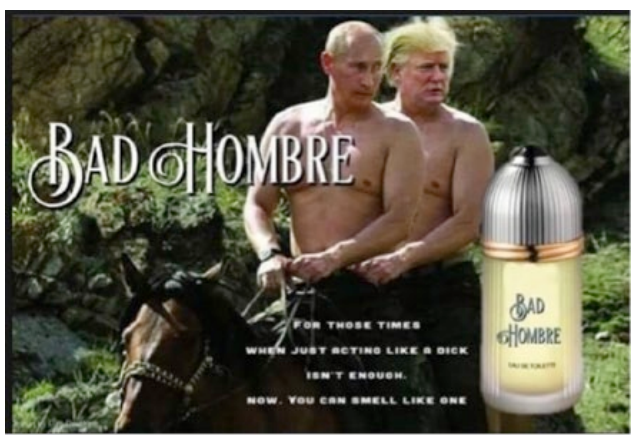

Figure I7. Trump and Putin as "bad hombres." Source: https://www.facebook.com/TheLiberalVoiceOfReason/.

targeted by his proposed U.S.-Mexico border wall. Using this single Spanish word in an otherwise monolingual English speech serves to reference the population that would understand this term. Although hombres directly translates to men, in this context, it implies Mexican immigrants, thus reifying the construction of Mexican men as "inherently undesirable, 'illegal,' criminal, violent" (Schwartz 2016). In reaction, some tried to reverse the insult by applying it to Trump and transforming its ethnic interpretation to a sexual one. However, while Nasty Woman was successfully redefined as an empowering term, Bad Hombre was redefined as an emasculating sexual term and in doing so, reified a heteronormative, homophobic gender structure. Despite the intention to turn the insult on Trump, it ultimately reaffirmed a heteronormative structure of oppression by implying that if Trump were gay, he would be less fit for the presidency.

Figure 17 not only critiques Trump's language of "bad hombres" and his conflict of interests with Russia but also ties Trump's enactment of hypermasculinity to Putin's. In such a way, the meme is critical of the hegemonic masculinity implicit in Trump's rhetoric but intentionally or not perpetuates these scripts by implying homosexuality is emasculating and thereby makes someone unfit for presidency (Pascoe 2012).

\section{Conclusions}

When asked at the end of the second presidential debate what they respected about one another, Trump said about Clinton, "She's a fighter. I disagree with much of what she's fighting for. I do disagree with her judgment in many cases. But she does fight hard and she doesn't quit and she doesn't give up" (Mangan 2016). While this would be considered a compliment to a man running for presidential office, this language connotes the same political humor that constructed Clinton's "excessive ambition, cruelty, aggression, fearlessness, hunger for power and control ... in phallic terms, since that is the culture-wide symbolic shorthand for these 'masculine' qualities" (Ducat 2004:139). Being a "fighter" connotes violence and masculinity, qualities she must have to be considered for a traditionally male position in a patriarchal society but that characterizes her as insufficiently feminine.

When asked what she respected about Trump, Clinton responded, "I respect his children. His children are incredibly able and devoted, and I think that says a lot about Donald" (Mangan 2016). While Clinton may have sought to feminize Trump by defining him by his children (and calling him by his first name), it is important to note that his children were largely raised by their single mothers given that he divorced his first three wives before marrying his current wife, Melania. Therefore, his influence was mostly in the form of monetary contributions, reflecting a traditionalist father-as-breadwinner, mother-as-homemaker division of labor that reaffirms the legitimacy of his elevated status within the patriarchy.

These "compliments" reflect just how ingrained gender was in the 2016 U.S. presidential race. The present analysis of political humor further reveals how central hegemonic masculinity figured into the discursive definitions of presidential fitness. Specifically, this analysis revealed recurrent themes of the body, virility, (sexual) dominance, control, gender conformity, heteronormativity, and whiteness within political cartoons, memes, and tweets that critiqued the two frontrunners, Hillary Clinton and Donald Trump. These themes coalesced in two common configurations: (1) humor attacking Hillary for being inappropriately masculine (domineering other men) and inappropriately feminine (an inadequately sexually desirable body and overly aggressive) (46/109, or 42 percent, of jokes about Hillary) and (2) humor attacking Trump for being inappropriately masculine in terms of his lack of phallus (small hands, small stature), femininity, sexuality, and lack of control (58/115, or 50 percent, of jokes about Trump). As such, political critiques were often accomplished by reaffirming scripts of hegemonic masculinity and patriarchal legitimacy. While there is no ubiquitous male, the performance associated with hegemonic masculinity is of a man who "must impregnate women, protect dependents from danger, and provision kith and kin.... We might call this quasi-global personage something like 'Manthe-Impregnator-Protector-Provider" (Gilmore 1990:223). Through his own bravado and with the aid of political humor, Donald Trump was discursively constructed as that very man. It is important to note how Hillary Clinton and Donald Trump's personas were as much created by these memes as they were by the politicians themselves. The collective constructions and interpretations are equally-if not moremeaningful to the collective imaginary than the actions or words on the campaign trail.

It is also worth noting that much of the humor critiquing Trump may have appeared obvious or redundant if applied to Clinton, who, because of her gender, was deemed unpresidential from the start (Ducat 2004). For example, if Clinton had cared about her appearance, it would have been coded as "natural" and also serve as evidence for her incompetence as president as she would care about frivolous things. If Clinton 
appeared as a puppet, it would fit into narratives about feminine subservience, and it would make her an incompetent president who lacks control. If Clinton accused Trump of being nasty (despite his history of sexual assault), it would make her predictably, femininely "petty," and it would suggest presidential incompetence. The humor may have tried to craft Trump as "more feminine" than Clinton, but by resorting to such gendered and heteronormative discourses, they reaffirmed the assumption that "presidential" is necessarily masculine and heterosexual. As a result, such humor "can reinscribe and exacerbate already existing gendered, classed, and raced inequalities" (Pascoe 2017:137). Treating masculinity as a vehicle for power justifies patriarchy, chauvinism, misogyny, homophobia, and racism as legitimation tools to justify one's current or aspirational power.

These findings imply that women cannot compete among men by playing by the same rules, by performing masculinity and dominance. This was most evident in humor that targeted Clinton for (arguably) seeking to accomplish just that. Instead of asking our candidates to ascribe to these extreme gender scripts, we need to change what actions get coded as successful or productive so that we elect leaders who are intelligent, compassionate, visionary, and successful at promoting equitable and progressive policy (Messner 2007). Feminist scholarship promotes such an approach that encourages building coalitions between different groups who are subjugated or excluded in the white patriarchy while simultaneously recognizing their unique challenges and perspectives. The important first step is identifying those contradictions within our national discourse, in that without their resolution, change is impossible. Humor is an important window into these unresolved tensions as those discourses that produce laughter and meaning for the audience may reveal the undergirding structures of power that get masked by political and popular discourse.

\section{Acknowledgments}

I would like to thank Jenny Huberman and Valerie Chepp for their insightful comments on an earlier version of this manuscript as well as the two anonymous reviewers who provided elucidative and directive feedback.

\section{References}

Anderson, Benedict. 1991. Imagined Communities: Reflections on the Origin and Spread of Nationalism. London: Verso.

Anderson, Monica, and Andrew Perrin. 2016. "13\% of Americans Don't Use the Internet. Who Are They?" Accessed September 7, 2016 (http://www.pewresearch.org/fact-tank/2016/09/07/ some-americans-dont-use-the-internet-who-are-they/).

Barber, Kristen. 2008. "The Well-coiffed Man: Class, Race, and Heterosexual Masculinity in the Hair Salon." Gender \& Society 22(4):455-76.

Billig, Michael. 2005. Laughter and Ridicule: Toward a Social Critique of Humour. London: Sage.
Bird, Sharon. 1996. "Welcome to the Men's Club: Homosociality and the Maintenance of Hegemonic Masculinity." Gender \& Society 10(2):120-32.

Bordo, Susan. 1999. The Male Body: A New Look at Men in Public and in Private. New York: Macmillan.

Bordo, Susan. 2003. Unbearable Weight: Feminism, Western Culture, and the Body. Berkeley, CA: University of California Press.

Bordo, Susan. 2017. The Destruction of Hillary Clinton. New York: Melville House.

Brady, Timothy F., Talia Konkle, George A. Alvarez, and Aude Olivia. 2008. "Visual Long-term Memory Has a Massive Storage Capacity for Object Details." PNAS 105(38):1432529.

Bridges, Tristan. 2010. "Men Just Weren't Made To Do This: Performances of Drag at 'Walk a Mile in Her Shoes' Marches." Gender \& Society 24(1):5-30.

Clarke, Adele E. 2003. "Situational Analysis: Grounded Theory Mapping after the Postmodern Turn." Symbolic Interaction 26:553-76.

Clarke, Adele E. 2005. Situational Analysis: Grounded Theory after the Postmodern Turn. Thousand Oaks, CA: Sage.

Collins, Patricia H. 1990. Black Feminist Thought: Knowledge, Consciousness, and the Politics of Empowerment. Boston: Unwin Hyman.

Collins, Patricia H. 1992. "Transforming the Inner Circle: Dorothy Smith's Challenge to Sociological Theory." Sociological Theory 10:73-80.

Collins, Patricia H. 1998. "It's All in the Family: Intersections of Gender, Race, and Nation." Hypatia 13(3):62-82.

Collins, Patricia H. 2006. "A Telling Difference." Pp. 73-98 in Progressive Black Masculinities?, edited by A. D. Mutua. New York: Routledge.

Colvin, Jill. 2016. "Trump Accuses of Clinton of 'Using the Woman Card' to Boost her Appeal." Business Insider. Retrieved December 15, 2017 (http://www.businessinsider.com/trumpclinton-woman-card-2016-8).

Connell, R. W. 1987. Gender and Power. Sydney: Allen and Unwin.

Connell, R. W. 1995. Masculinities. Berkeley: University of California Press.

Connell, R. W., and James Messerschmidt. 2005. "Hegemonic Masculinity: Rethinking the Concept." Gender \& Society 19(6):829-59.

Critchley, Simon. 2002. On Humor. New York: Routledge.

Doyle, Sady. 2016. "America Loves Women Like Hillary Clinton-As Long as They're Not Asking for a Promotion." Quartz. Retrieved February 25, 2016 (https://qz.com/624346/ america-loves-women-like-hillary-clinton-as-long-as-theyrenot-asking-for-a-promotion/).

Ducat, Stephen. 2004. The Wimp Factor: Gender Gaps, Holy Wars, and the Politics of Anxious Masculinity. Boston: Beacon Press.

Dundes, Alan, and Carl Pagter. 1991. "The Mobile SCUD Missile Launcher and Other Persian Gulf Warlore: An American Folk Image of Saddam Hussein's Iraq." Western Folklore 50(3):303-22.

Fouacult, Michel. 1977. Discipline and Punish: The Birth of the Prison. New York: Vintage Books.

Frej, Willa. 2016. "Here's a Running List of Racist Things That Have Happened at Trump Rallies." Huffington Post. 
Retrieved March 2, 2016 (https://www.huffingtonpost.com/ entry/list-racist-things-trump-rallies_us_56d7019ae4b0871f6 0ed519f).

Frye, Marilyn. 1983. The Politics of Reality. Trumansburg, NY: The Crossing Press.

Gilmore, David. 1980. Manhood in the Making: Cultural Concepts of Masculinity. New Haven, CT: Yale University Press

Glaser, Barney G., and Anselm L. Strauss. 1967. The Discovery of Grounded Theory. New York: Aldine.

Goffman, Erving. 1959. The Presentation of Self in Everyday Life. New York: Anchor Books.

Gottfried, Jeffrey, and Elisa Shearer. 2016. "News Use across Social Media Platforms 2016.” Retrieved May 26, 2016 (http:// www.journalism.org/2016/05/26/news-use-across-socialmedia-platforms-2016/).

Gramsci, Antonio, Quentin Hoare, and Geoffrey Nowell-Smith. 1971. Selections from the Prison Notebooks of Antonio Gramsci. New York: International Publishers.

Greenhouse, Emily. 2015. "Donald Trump May Be the Most Quotable Man in the Politics, but He Outdid Himself in an Interview Published Monday by the Des Moines Register." Retrieved June 1, 2015 (https://www.bloomberg.com/politics/ articles/2015-06-01/donald-trump-i-m-the-most-successfulperson-ever-to-run-for-the-presidency-).

Henley, Nancy. 1977. Body Politics: Power, Sex, and Nonverbal Communication. Englewood Cliffs, NJ: Prentice-Hall.

Herzfeld, Michael. 1997. Cultural Intimacy: Social Poetics in the Nation-state. New York: Routledge.

Hlavka, Heather R. 2014. "Normalizing Sexual Violence: Young Women Account for Harassment and Abuse." Gender \& Society 28(3):337-58.

Hochschild, Arlie R. 2016. Strangers in Their Own Land: Anger and Mourning on the American Right. New York: The New Press.

Hollander, Jocelyn A., and Rachel Einwohner. 2004. "Conceptualizing Resistance.” Sociological Forum 19(4):533-54.

Holley, Peter. 2016. "KKK's Official Newspaper Supports Donald Trump." The Washington Post. Retrieved November 1, 2016 (https://www.washingtonpost.com/news/post-politics/ wp/2016/11/01/the-kkks-official-newspaper-has-endorseddonald-trump-for-president/).

Johnson, Allan G. 2005. The Gender Knot: Unraveling Our Patriarchal Legacy. Philadelphia: Temple University Press.

Katz, Jackson. 2016. Man Enough? Donald Trump, Hillary Clinton, and the Politics of Presidential Masculinity. Northhampton, MA: Interlink Books.

Kimmel, Michael, and Rebecca Plante. 2005. "The Gender of Desire: The Sexual Fantasies of Women and Men. Pp. 55-77 in Advances in Gendered Sexualities. Vol. 6, edited by P. Gagné, and R. Tewks. Bingley, UK: Emerald Group Publishing Limited.

Kleinman, Sherryl, Matthew Ezzell, and A. Corey Frost. 2009. "Reclaiming Critical Analysis: The Social Harms of 'Bitch."” Sociological Analysis 3:46-68.

Krieg, Gregory. 2016. "Donald Trump Defends Size of His Penis." CNN. Retrieved March 4, 2016 (http://www.cnn. com/2016/03/03/politics/donald-trump-small-hands-marcorubio/index.html).

Leeming, David. 2005. The Oxford Companion to World Mythology. New York: Oxford University Press.
Little, Anthony C., S. Craig Roberts, Benedict C. Jones, and Lisa M. DeBruine. 2012. "The Perception of Attractiveness and Trustworthiness in Male Faces Affects Hypothetical Voting Decisions Differently in Wartime and Peacetime Scenarios." Quarterly Journal of Experimental Psychology 65(10): 2018-32.

Lorber, Judith. 2005. Breaking the Bowls: Degendering and Feminist Change. New York: W.W. Norton.

Luker, Kristin. 2008. Salsa Dancing into the Social Sciences: Research in an Age of the Info-glut. Cambridge, MA: Harvard University Press.

Mangan, Dan. 2016. "Trump Compliments Clinton: She's a Fighter." CBS News. Retrieved October 9, 2016 (https://www. cnbc.com/2016/10/09/trump-compliments-clinton-shes-afighter.html).

Mbembe, Achille. 2001. On the Postcolony. Berkeley: University of California Press.

McClintock, Anne. 1995. Imperial Leather: Race, Gender and Sexuality in the Colonial Conquest. New York: Routledge.

Messner, Michael. 2007. "The Masculinity of the Governator: Muscle and Compassion in American Politics." Gender \& Society 21(4):461-80.

Nagel, Joane. 1998. "Masculinity and Nationalism: Gender and Sexuality in the Making of Nations." Ethnic and Racial Studies 21:242-69.

Pascoe, C. J. 2012. Dude, You 're a Fag: Masculinity and Sexuality in High School. Berkeley: University of California Press.

Pascoe, C. J. 2017. "Who Is a Real Man? The Gender of Trumpism." Masculinities \& Social Change 6(2):119-41.

Pascoe, C. J., and Jocelyn A. Hollander. 2016. "Good Guys Don't Rape: Gender, Domination, and Mobilizing Rape.” Gender \& Society 30(1):67-79.

Renner, N. 2017. "Meme's Trump Memes on Breitbart's Facebook Page." Colombia Journalism Review. Retrieved January 30, 2017 (http://www.cjr.org/tow_center/memes-trump-articleson-breitbarts-facebook-page.php).

Rogers, S. M. 2014. "What Fuels a Tweet's Engagement?" Retrieved December 15, 2017 (https://blog.twitter.com/2014/ what-fuels-a-tweets-engagement).

Ross, Phillip. 2014. "Photos Are Still King on Facebook." Retrieved December 15, 2017 (https://www.socialbakers.com/blog/2149photos-are-still-king-on-facebook).

Schreckinger, Ben. 2017. "The Great Meme War." Politico. Retrieved December 15, 2017 (http://www.politico.com/magazine/story/2017/03/memes-4chan-trump-supporters-trollsinternet-214856).

Schwartz, Adam. 2016. "Trump Relies on Spanish to Talk about Immigration.” Retrieved October 20, 2016 (http://www.latinorebels.com/2016/10/20/trump-relies-on-mock-spanish-totalk-about-immigration-opinion/).

Scott, James C. 1990. Domination and the Arts of Resistance: Hidden Transcripts. New Haven, CT: Yale University Press.

Sheeler, Kristina, and Karrin Anderson. 2013. Woman President: Confronting Postfeminist Political Culture. College Station: Texas A\&M University Press.

Smirnova, Michelle. 2014. "What Is the Shortest Russian Joke? Communism. Russian Cultural Consciousness Expressed through Soviet Humor." Qualitative Sociology 37:323-43. 
Smirnova, Michelle. 2016. "Multiple Masculinities: Gender Performativity in Soviet Humor." Men \& Masculinities 20(2):204-29.

Stroud, Angela. 2012. "Good Guys with Guns: Hegemonic Masculinity and Concealed Handguns." Gender \& Society 26(2):216-38.

Taussig, Michael. 1999. Defacement: Public Secrecy and the Labor of the Negative. San Francisco, CA: Stanford University Press.

Tavory, Iddo. 2014. "The Situations of Culture: Humor and the Limits of Measurability." Theory \& Society 43(3):275-89.

Timmermans, Stephan, and Iddo Tavory. 2012. "Theory Construction in Qualitative Research: From Grounded Theory to Abductive Analysis." Sociological Theory 30(3): 167-86.

Van Dijk, Teun. 1997. Discourse Studies: A Multidisciplinary Introduction. London: Sage.
Van Dijk, Teun. 2001. “Critical Discourse Analysis.” Pp. 352-71 in Handbook of Discourse Analysis, edited by D. Tannen, D. Schiffrin, and H. Hamilton. Oxford: Blackwell.

Van Dijk, Teun. 2008. Discourse and Context. A Sociocognitive Approach. Cambridge: Cambridge University Press.

West, Candace, and Sarah Fenstermaker. 1995. "Doing Difference." Gender \& Society 9(1):8-37.

West, Candace, and Don H. Zimmerman. 1987. "Doing Gender." Gender \& Society 1(2):125-51.

\section{Author Biography}

Michelle Smirnova is an assistant professor of sociology and associate faculty member of the Women's, Gender, and Sexuality Studies program at the University of Missouri in Kansas City. Her research expertise includes the sociology of humor, medicine, gender, social theory, and cultural expressions of power and resistance. 